\title{
Using Genetic Engineering Techniques to Develop Banana Cultivars With Fusarium Wilt Resistance and Ideal Plant Architecture
}

\author{
Xiaoyi Wang ${ }^{1 \dagger}$, Renbo $\mathrm{Yu}^{2 \dagger}$ and Jingyang $\mathrm{Li}^{{ }^{*}}$ \\ ${ }^{1}$ Key Laboratory of Genetic Improvement of Bananas, Haikou Experimental Station, Chinese Academy of Tropical \\ Agricultural Sciences, Haikou, China, ${ }^{2}$ Key Laboratory of Vegetable Research Center, Tropical Crops Genetic Resources \\ Institute, Chinese Academy of Tropical Agricultural Sciences, Haikou, China
}

OPEN ACCESS

Edited by:

Nicolas Rispail,

Spanish National Research Council,

Spain

Reviewed by:

Chunyu Li,

Guangdong Academy of Agricultural

Sciences (IFTR, GDAAS), China

Siddhesh B. Ghag,

UM-DAE Centre for Excellence

in Basic Sciences, India

*Correspondence:

Jingyang $L i$

jingyanglee@163.com

${ }^{\dagger}$ These authors have contributed equally to this work

Specialty section:

This article was submitted to

Plant Breeding,

a section of the journal

Frontiers in Plant Science

Received: 14 October 2020 Accepted: 16 December 2020

Published: 13 January 2021

Citation:

Wang X, Yu R and Li J (2021)

Using Genetic Engineering

Techniques to Develop Banana

Cultivars With Fusarium Wilt

Resistance and Ideal Plant

Architecture.

Front. Plant Sci. 11:617528.

doi: 10.3389/fpls.2020.617528
Bananas (Musa spp.) are an important fruit crop worldwide. The fungus Fusarium oxysporum f. sp. cubense (Foc), which causes Fusarium wilt, is widely regarded as one of the most damaging plant diseases. Fusarium wilt has previously devastated global banana production and continues to do so today. In addition, due to the current use of high-density banana plantations, desirable banana varieties with ideal plant architecture (IPA) possess high lodging resistance, optimum photosynthesis, and efficient water absorption. These properties may help to increase banana production. Genetic engineering is useful for the development of banana varieties with Foc resistance and ideal plant architecture due to the sterility of most cultivars. However, the sustained immune response brought about by genetic engineering is always accompanied by yield reductions. To resolve this problem, we should perform functional genetic studies of the Musa genome, in conjunction with genome editing experiments, to unravel the molecular mechanisms underlying the immune response and the formation of plant architecture in the banana. Further explorations of the genes associated with Foc resistance and ideal architecture might lead to the development of banana varieties with both ideal architecture and pathogen super-resistance. Such varieties will help the banana to remain a staple food worldwide.

\footnotetext{
Keywords: banana (Musa spp.), Foc resistance, ideal plant architecture, genetic engineering, genome editing, functional genomics study
}

\section{INTRODUCTION}

Bananas (Musa ssp.), which originated in Southeast Asia, are widely cultivated throughout the tropics and sub-tropics, where they represent part of the staple diet and are a vital source of nutrition for over 500 million people (Wang et al., 2019). Due to their widespread popularity, bananas have the largest market share of any fruit worldwide (Langhe et al., 2008). Because bananas are nutritious and starchy, they are considered the fourth most important food crop after rice, wheat, and maize for the alleviation of human starvation in Africa by the United Nations Food and Agriculture Organization (Song et al., 2018). In 2019, worldwide banana production was over 113 million tons; the two largest producers of bananas are India (36.7\%) and China (13.8\%) (Tzean et al., 2019). 
Banana plantations are seriously threatened by various biotic and abiotic stresses, such as diseases, drought, and low temperatures (Michael and Abdou, 2011; Tripathi et al., 2015). At present, the major threat to global banana production is Foc, the causative pathogen of Panama disease, which can completely devastate the banana plant. Once established, Fusarium cannot be controlled by any chemical or physical means (Dita et al., 2018). Thus, due to the nutritional and economic importance of bananas, there is a pressing need to develop new cultivars that tolerate Foc infection.

In addition, there is a need for bananas with improved plant architecture. This is because, to increase banana production, bananas on small plantations are grown at increasingly high densities (Dash and Rai, 2016). However, dense planting induces competition for light, water, and nutrients (Tian et al., 2019). Thus, the ideal banana architecture includes moderate height, compact leaf angle, and a root system with good hydrotropism; the development of varieties with these characteristics will help to increase banana production (Jiao et al., 2010; Kitomi et al., 2015; Dash and Rai, 2016). However, most widely grown banana varieties with excellent production are Foc susceptible, and most Foc-resistant banana varieties are poor producers (HeslopHarrison and Schwarzacher, 2007). To solve this problem, methods should be developed to improve Foc resistance as well as plant architecture in bananas, and to balance the need for Foc resistance against the need for high production.

The most important cultivated banana varieties worldwide are triploid and originated from the inter- or intra-specific hybridization of two wild diploid species, Musa acuminate (A genome) and M. balbisiana (B genome) (Wang et al., 2019). Therefore, most banana cultivars are sterile and genetic diversity is narrow, meaning that conventional breeding in this crop is challenging (Heslop-Harrison and Schwarzacher, 2007). Genetic modification may represent a powerful alternative to traditional breeding in bananas, as this method bypasses reproductive barriers and supports the development of improved strains based on excellent cultivars.

Most of the genetic modification methods commonly used in bananas were developed in the 1990s, including protoplast electroporation (Sági et al., 1994), particle bombardment (Sági et al., 1995), and Agrobacterium-mediated transformation (May et al., 1995). Embryogenic cell suspensions (ECS) are typical targets of genetic transformation in bananas, and ECS regeneration systems have been established for several banana varieties (Novak et al., 1989; Hu et al., 2013; Dale et al., 2017). To date, several improved transgenic banana varieties with Foc resistance and ideal plant architecture have been developed (Table 1). However, the mechanisms underlying Foc resistance and ideal plant architecture formation, as well as some critical genes associated with these processes, remain unknown in bananas. The rapid development of genetic engineering techniques, as well as the publication of the banana genome, will greatly facilitate further genetic improvements in bananas (D’Hont et al., 2012; Maxmen, 2019; Wang et al., 2019).

This study had three main aims: first, to present genetic improvements in Foc resistance and plant architecture traits in bananas, with emphasis on those characteristics that are important for banana breeding and those where the underlying molecular mechanisms require further study; second, to show that future efforts to improve Foc resistance must also consider the production penalties; and third, to outline the present state of banana genetic transformation technology, and to describe the prospective applications of newly developed genome editing systems in banana breeding.

\section{GENETIC ALTERATIONS TO IMPROVE FOC TOLERANCE}

Fusarium wilt, also known as Panama disease, is one of the most well-known banana disease. This disease, which is caused by the soil-borne fungus Foc, destroys the banana plant (Stover and Simmonds, 1987). Foc includes four physiologically distinct races: Race 1, Race 2, Race 3, and Race 4; each race has different effects on different host cultivars (Ploetz, 2006; Swarupa et al., 2014). In the 1950s, Foc Race 1 devastated the then-dominant cultivar Gros Michel worldwide, leading to the complete replacement of Gros Michel with Foc Race 1-resistant Cavendish cultivars (Dita et al., 2018). In the 1990s, another virulent form of Foc, tropical race 4 (TR4) seriously damaged Cavendish banana production in Asia (Ploetz, 2006). Since that time, TR4 has invaded Oceania, Australia, and has now reached the Americas (Ploetz, 2006; Maxmen, 2019). Because Foc can survive in soil for more than 30 years, it is easily spread by people or equipment carrying contaminated soil (Maxmen, 2019). Once infected with TR4, bananas exhibit discoloration, followed by necrosis in the root and rhizome; due to necrosis, water, and nutrients are not transported, leading to withering and, eventually, the death of the entire plant (Stover and Simmonds, 1987). There is no effective chemical or biological control for TR4 (Dita et al., 2018). As commercially cultivated bananas are sterile and propagated via vegetative suckers, it is not possible to use conventional crossbreeding methods to develop resistance to this fungus. Therefore, global banana production may be seriously devastated by Foc in the future unless genetically modified varieties with TR4 resistance are developed (Maxmen, 2019). Several genes that have been used in attempts to develop Foc TR4 resistance in bananas are listed in Table $\mathbf{1 .}$

The majority of the transgenic bananas with Foc resistance have been developed using antifungal proteins from other crops, such as defensins and ferredoxin-like proteins (Ghag et al., 2012; Sunisha et al., 2020). Transgenic bananas expressing two defensins genes from Petunia flowers were more resistant to Foc Race 1 (Ghag et al., 2012), while those expressing a rice thaumatin-like protein $(t l p)$ gene were more resistant to Foc Race 4 (Mahdavi et al., 2012). Additionally, potted banana plants transformed with two genes encoding antimicrobial peptides, antimicrobial peptide (Ace-AMP1) and ferredoxin-like protein $(p f l p)$, exhibited increased resistance to Foc Race 1 (vascular discoloration index of 10-20\%) as compared to non-transgenic plants (vascular discoloration index of 96\%) (Sunisha et al., 2020). Ace-AMP1 is a non-specific lipid transfer protein (nsLTPs) from Allium cepa that binds to a signaling receptor to induce a defense response, while the plant pflp gene from Capsicum annum 
TABLE 1 | Improved agricultural traits in transgenic bananas (Musa spp.).

\begin{tabular}{|c|c|c|c|c|c|c|c|c|}
\hline Trait & Line & Genotype & $\begin{array}{l}\text { Explant } \\
\text { tissue }\end{array}$ & $\begin{array}{l}\text { Agrobacterium } \\
\text { strain }\end{array}$ & Plasmid & Promoter & Transformed gene & References \\
\hline $\begin{array}{l}\text { Foc Race } 2 \\
\text { resistance }\end{array}$ & - & Rasthali (AAB) & ECS & EHA105 & pGFP100 & pAtUbq3 & MSI-99 & $\begin{array}{c}\text { Chakrabarti et al. } \\
\text { (2003) }\end{array}$ \\
\hline \multirow[t]{5}{*}{$\begin{array}{l}\text { Foc Race } 1 \\
\text { resistance }\end{array}$} & VCG 01217 & Rasthali (AAB) & Single buds & LBA4404 & pROKla & CaMV35S & GmEg & $\begin{array}{l}\text { Maziah et al. } \\
\qquad(2007)\end{array}$ \\
\hline & VCG 0124/5 & $\begin{array}{l}\text { Lady Finger } \\
\qquad(\mathrm{AAB})\end{array}$ & ECS & LBA4404 & $\begin{array}{c}\text { pPTN254, pPTN261, } \\
\text { pPTN396, }\end{array}$ & pZmUbi & $\begin{array}{c}\text { Bcl-xL, Ced-9, Bcl-2 } \\
\text { 3' UTR }\end{array}$ & Paul et al. (2011) \\
\hline & - & Rasthali (AAB) & ECS & EHA105 & pCAMBIA1301 & pZmUbi & PhDef1, PhDef2 & Ghag et al. (2012) \\
\hline & - & Rasthali (AAB) & ECS & EHA105 & $\begin{array}{c}\mathrm{pCAMBIA1301}+ \\
\text { pTZ57R/T }\end{array}$ & pZmUbi & $\begin{array}{l}\text { VELsen-Int-VELas, } \\
\text { FTF1sen-Int-FTF1as }\end{array}$ & Ghag et al. (2014) \\
\hline & - & Rasthali (AAB) & ECS & AGL1 & pCAMBIA1305.2 & CaMV35S, pZmUbi & $\begin{array}{c}\text { Ace-AMP1 + } \\
\text { Ca-pflp }\end{array}$ & $\begin{array}{l}\text { Sunisha et al. } \\
\text { (2020) }\end{array}$ \\
\hline \multirow[t]{7}{*}{ TR4 resistance } & - & Taijiao (AAA) & Corm slices & $\begin{array}{c}\text { Naked gold } \\
\text { Particle } \\
\text { bombardment + } \\
\text { EHA105 }\end{array}$ & pCAMBIA1301 & CaMv35S & Human lysozyme & Pei et al. (2005) \\
\hline & - & $\begin{array}{c}\text { Pei Chiao (AAA) } \\
\text { or Gros Michel } \\
\text { (AAA) }\end{array}$ & $\mathrm{MBC}$ & C58C1 or EHA105 & $\mathrm{pBl} 121$ & CaMV35S & Atfd3, Ca-pflp & Yip et al. (2011) \\
\hline & VCG 1213/16 & $\begin{array}{l}\text { Pisang Nangka } \\
\text { (AAB) }\end{array}$ & CLBs & $\begin{array}{c}\text { Particle } \\
\text { bombardment }\end{array}$ & pCambia1304 & CaMV35S & OsTLP & $\begin{array}{l}\text { Mahdavi et al. } \\
\qquad(2012)\end{array}$ \\
\hline & VCG 01213 & Furenzhi (AA) & ECS & EHA105 & pCAMBIA1301 & CaMv35s & ThChit42 & Hu et al. (2013) \\
\hline & - & Williams (AAA) & ECS & EHA105 & $\begin{array}{l}\text { pCAMBIA1301, } \\
\text { pRiAT }\end{array}$ & CaMV35S & $\begin{array}{c}\text { MaLYK1, The sense } \\
\text { and antisense } \\
\text { fragments of } \\
\text { MaLYK1 }\end{array}$ & $\begin{array}{l}\text { Zhang et al. } \\
\text { (2019b) }\end{array}$ \\
\hline & - & $\begin{array}{l}\text { Grand Nain } \\
\text { (AAA) }\end{array}$ & ECS & AGL1 & $\begin{array}{l}\text { pCAMBIA2200, } \\
\text { PPTN261 }\end{array}$ & Nos-P, pZmUbi & RGA2, Ced-9 & Dale et al. (2017) \\
\hline & - & Cavendish (AAA) & ECS & EHA105 & pCAMBIA1301 & pZmUbi & ERG6, ERG11 & Dou et al. (2019) \\
\hline Plant height & & $\begin{array}{l}\text { Gros Michel } \\
\text { (AAA) }\end{array}$ & ECS & EHA105 & $\begin{array}{l}\text { pYLCRISPR/ } \\
\text { Cas9P ubi-H }^{-H}\end{array}$ & OsU6a+Osu3 & $\begin{array}{c}\text { sgRNA of } \\
\text { MaGA20ox2 }\end{array}$ & Shao et al. (2019) \\
\hline \multirow[t]{8}{*}{$\begin{array}{l}\text { Drought } \\
\text { tolerance }\end{array}$} & & Rasthali (AAB) & MSCs & EHA105 & pCAMBIA1301 & pZmUbi & MaDHN-1 & $\begin{array}{c}\text { Shekhawat et al. } \\
\text { (2011b) }\end{array}$ \\
\hline & & Rasthali (AAB) & ECS & EHA105 & pCAMBIA1301 & pZmUbi & MaSAP1 & $\begin{array}{l}\text { Sreedharan et al. } \\
\qquad(2012)\end{array}$ \\
\hline & & Rasthali (AAB) & ECS & EHA105 & pCAMBIA1302 & CaMV35S & MaWRKY71 & $\begin{array}{l}\text { Shekhawat and } \\
\text { Ganapathi (2013) }\end{array}$ \\
\hline & & Rasthali (AAB) & ECS & EHA105 & pCAMBIA1301 & pZmUbi & MaSNAC1 & Negi et al. (2018) \\
\hline & & Rasthali (AAB) & ECS & EHA105 & pCAMBIA1302 & CaMV35S & MaNAC042 & Tak et al. (2017) \\
\hline & & Rasthali (AAB) & ECS & EHA105 & pCAMBIA1301 & pZmUbi & MaPIP1;2 & $\begin{array}{l}\text { Sreedharan et al. } \\
\qquad(2013)\end{array}$ \\
\hline & & Rasthali (AAB) & ECS & EHA105 & pCAMBIA1301 & pZmUbi, pMaDHN-1 & MaPIP2;6 & $\begin{array}{l}\text { Sreedharan et al. } \\
\qquad(2015)\end{array}$ \\
\hline & & Gongjiao (AA) & $\begin{array}{l}\text { Thin cell layers } \\
\text { from shoot tips }\end{array}$ & EHA105 & pCAMBIA1302 & CaMV35S & MaPIP2;7 & Xu et al. (2020) \\
\hline \multirow{2}{*}{$\begin{array}{l}\text { Secondary wall } \\
\text { deposition }\end{array}$} & & Rasthali (AAB) & ECS & EHA105 & pCAMBIA1301 & pZmUbi & MusaVND1 & Negi et al. (2015) \\
\hline & & Rasthali (AAB) & ECS & EHA105 & pCAMBIA1301 & pZmUbi & $\begin{array}{l}\text { MusaVND2, } \\
\text { MusaVND3 }\end{array}$ & Negi et al. (2016b) \\
\hline
\end{tabular}

Foc, Fusarium oxysporum f. sp. cubense;

pZmUbi, the maize polyubiquitin promoter;

CLBs, cauliflower-like bodies, induced from the meristemic parts of male inflorescences;

MBCs, multiple bud clumps, induced from sucker buds;

MSCs, multiple shoot clumps;

ECS, embryogenic cell suspensions.

participates in the activation of the hypersentitive response, initiating systemic acquired resistance (Sunisha et al., 2020). Several other genes have also been overexpressed in bananas to increase Fusarium wilt resistance, such as the soybean $\beta-1,3-$ endoglucanase gene, a rice chitinase gene, a sweet pepper pflp gene, and synthetic analogs of magainin (MSI-99), and human lysozyme (HL) (Chakrabarti et al., 2003; Pei et al., 2005; Maziah et al., 2007; Yip et al., 2011).
Genes encoding chitinase, which hydrolyzes the main components of the fungal cell wall (chitin and $\beta$-glucan), have also been used successfully to inhibit phytopathogenic fungi in various crops (Girhepuje and Shinde, 2011; Chhikara et al., 2012; Das and Rahman, 2012; Nookaraju and Agrawal, 2012). For example, a secreted endochitinase gene from Trichoderma harzianum (chit42) improved tolerance to TR4 in transgenic bananas (Hu et al., 2013). Indeed, the levels of chit42 transcription 
in transgenic plants are proportional to the level of TR4 resistance (Hu et al., 2013).

Anti-apoptosis genes, which play significant roles in the inhibition of cell death, have been used to increase Foc resistance in bananas (Paul et al., 2011; Dale et al., 2017). In glasshouse trials, "Lady Finger" banana plants that had been transformed with various animal genes associated with apoptosis-inhibition [e.g., B-cell lymphoma-xl (Bcl-xL), Cell death protein-9 (Ced-9), and $\mathrm{Bcl}-23^{\prime}$ untranslated region ( $\left.3^{\prime} \mathrm{UTR}\right)$ ] exhibited improved resistance to Foc Race 1 (Paul et al., 2011). Similarly, transgenic bananas modified with the Ced9 anti-apoptosis gene from the nematode Caenorhabditis elegans showed improved resistance to TR4 in the field (Dale et al., 2017).

Banana-derived pathogen-resistance genes have also been used to increase disease resistance. For example, a 3 years field trial showed that TR4 resistance was improved in transgenic Cavendish varieties transformed with a resistance gene analog (RGA2) from the TR4-resistant wild banana Musa acuminate malaccensis (Dale et al., 2017). Similarly, transgenic banana plants overexpressing a banana lysine motif-containing receptorlike kinases 1 (MaLYK1) protein, which plays a role in TR4 resistance by mediating the conserved microbe-associated molecular pattern (MAMP)-activated defense response, had smaller leaf lesions after TR4 treatment than did wild type plants (Zhang et al., 2019b). Indeed, native Foc-resistant genes from a number of banana germplasms with Foc resistance, such as the double haploid variety Pahang, could be extracted and used to develop transgenic Foc-resistant cultivars (Dash and Rai, 2016). Functional genomics studies on these resistant bananas should be performed to reveal the molecular mechanisms underlying the immune response and to explore the important genes associated with Foc resistance. Such studies will promote the development of resistant germplasms using transgenic modification techniques.

\section{MECHANISMS UNDERLYING THE DEFENSE RESPONSE TO FOC IN PLANTS}

The defense mechanisms invoked in response to Foc have been investigated in model plants such Arabidopsis and tomatoes (Swarupa et al., 2014). Antimicrobial proteins from other crops have been used to improve Foc resistance in bananas using transgenic techniques (Swarupa et al., 2014). Due to host specificity, it is necessary to understand the immune mechanisms associated with Foc in bananas; this information is necessary to support the rational utilization of the banana's own resistanceconferring genes in transgenic Foc-resistant bananas.

The plant immune system has two layers that sense and defend against pathogens (Swarupa et al., 2014). The first layer is pathogen-triggered immunity (PTI), which is activated by pathogen recognition receptors (PRRs) located on the plant cell surface (Wang W. et al., 2020). In response, adapted pathogens secrete effector proteins to destroy the PTI. Then, the second layer of plant immunity, effector-triggered immunity (ETI), is elicited by the interaction of resistance (R) proteins with pathogen effector proteins (Wang W. et al., 2020). The
ETI process is accompanied by the rapid programmed death of the infected cells; this hypersensitive response, which represses pathogen growth and induces the release of toxic pathogenesisrelated proteins $(\mathrm{PR})$, is termed systemic acquired resistance (SAR) (Fu and Dong, 2013). Although two banana genes, a PRR gene (MaLYK1) and a nucleotide-binding and leucine-rich repeat type $\mathrm{R}$ gene ( $R G A 2)$, have been shown to play a role in Foc resistance, we still know little about the interaction between bananas and Foc (Dale et al., 2017; Zhang et al., 2019b). Using transcriptome profiles, it has been shown that the transcriptional levels of some genes are altered in Foc-resistant banana plants during the Foc defense response, suggesting that these genes may participate in Foc resistance (Li et al., 2012, 2013; Wang et al., 2012; Li W. et al., 2019; Zhang et al., 2019a). For example, several PRR genes, the glucanase gene, cell-wall-strengthening genes, reactive oxygen species (ROS)-scavenging enzyme genes, the non-expression of pathogenesis-related gene 1 (NPR1), and components of the ethylene (ET)/jasmonic acid (JA) biosynthesis and signaling pathway were upregulated in a Foc-resistant banana line as compared to a Foc-susceptible line in response to TR4 exposure (Li et al., 2012, 2013). Thus, transgenic analyses based on banana genomes should be used to clarify the functions of the identified genes in the Foc defense pathway (D'Hont et al., 2012; Wang et al., 2019). Importantly, the publication of the A-genome of a double-haploid M. acuminate genotype, DH-Pahang, which is highly resistant to TR4, may provide a valuable research target for studies of the interaction between bananas and Foc (D’Hont et al., 2012). Simultaneously, it is vital to investigate the mechanisms that sense Foc infection as well as the mechanisms by which R genes resist specific Foc effector proteins.

Although the plant immune system plays the primary role in pathogen defense, many environmental factors also heavily influence the interactions between plants and pathogens (Pegg et al., 2019). A dramatic example is the regulation of the plant immune response by light (Gao et al., 2020). As a soil-borne pathogen that infects plants through the roots (in the dark), Foc spreads via the vascular system to the aboveground part (in the light), leading to wilting and necrosis (Swarupa et al., 2014). During the infection process, the pathogen experiences a remarkable change in light quality and quantity. That is, the Foc infection travels upward along root vascular bundles to the corms and pseudostem of susceptible bananas, transitioning from dark to light during this process. However, this disease progression is nearly inhibited in resistant bananas (Li et al., 2013; Zhang et al., 2019a). It is possible that the light signaling pathway in resistant bananas helps to impede Foc progression through the lightexposed, aboveground portion of the plant. Therefore, studies of the effects of light on the Foc-banana interaction may help to clarify the immune process in bananas.

\section{GENETIC ALTERATIONS TO IMPROVE PLANT ARCHITECTURE}

Plant architecture, primarily plant height, is an important agronomic trait associated with crop yield (Wang B. et al., 2018). During the first "green revolution" in the middle of the 
twentieth century, the adoption of semi-dwarf rice, wheat, and maize varieties greatly improved crop production worldwide (Khush, 2001). As banana cultivars are typically more than 2-4 $\mathrm{m}$ high, they are vulnerable to lodging during extreme weather events, such as typhoons, and are then not suitable for harvesting (Dash and Rai, 2016). Therefore, dwarf banana cultivars are more suitable for modern intensive planting and fruit harvesting methods (Dash and Rai, 2016).

Semi-dwarf phenotypes of high-yielding varieties were developed during the "Green Revolution" using significant genetic mutations in the gibberellin (GAs) biosynthesis and signaling pathway (Wang et al., 2017). For example, mutations in the terpene synthase (TPS) gene, the P450 mono-oxygenases (P450s) gene, the GA 20-oxidase (GA20ox) gene, and the GA 3-oxidase (GA3ox) gene impair GA biosynthesis, resulting in the semi-dwarf phenotype (Wang et al., 2017). Recently, the Williams banana mutant, with reduced height compared to its parent, was developed; the reduced height of this mutant was mainly caused by the differential expression of genes involved in GA biosynthesis (Chen et al., 2016). Furthermore, the GA20ox2 gene has been modified in bananas using the clustered regularly interspaced short palindromic repeat (CRISPR)/CRISPR-associated protein 9 (Cas9) genome editing system to generate a semi-dwarf phenotype of the banana cultivar Gros Michel; this phenotype has lower levels of bioactive GA than the non-transgenic cultivar (Shao et al., 2019). Plant height is also determined by several other hormones, including auxin, brassinosteroids, and strigolactone (Wang B. et al., 2018). For example, the rice dwarf61 (d61), dwarf14 (d14), and lazy1 mutants exhibit semi-dwarf phenotypes due to inhibited brassinosteroid, strigolactone, and auxin signaling, respectively (Li et al., 2007; Zhao et al., 2014; Wang B. et al., 2018).

Ideally, banana plants should have thick, sturdy stems to improve lodging resistance during adverse weather events, such as typhoons. Increases in secondary wall deposition not only reduce lodging, but also increase plant lignocellulosic biomass (Velasquez Arredondo et al., 2010). Transcription factor NAC plays an important role in the regulation of secondary wall deposition (Negi et al., 2015). In bananas overexpressing MaVND1, MaVND2, and MaVND3, all of which contain an NAC domain, various types of cells transdifferentiated into tracheary element-like cells; in these transgenic bananas, genes associated with xylogenesis were expressed, and ectopic deposition of lignin were observed in various cells (Negi et al., 2015, 2016b). Characterization of the NAC family genes that participate in secondary wall deposition may support the future development of transgenic bananas with improved lodging resistance.

Due to their shallow roots and permanent green canopy, bananas are especially sensitive to water-associated stressors, such as drought and salinity (Sreedharan et al., 2013). In addition, banana roots that are grown under abiotic stress are usually more susceptible to Foc, exacerbating decreases in production (Krishna et al., 2015; Pegg et al., 2019). Several genes associated with drought resistance, including those encoding transcription factors (TFs) (e.g., MaSAP1, MaWRKY71, and MaNAC), aquaporins (e.g., MaPIP1;2, MaPIP2;6, and MaPIP2;7), and dehydrin (e.g., $M a D H N-1$ ) have been successfully incorporated into bananas, and these transgenic lines have developed improved root architecture and increased resistance to drought (Table 1; Shekhawat et al., 2011a; Sreedharan et al., 2012, 2013, 2015; Shekhawat and Ganapathi, 2013; Negi et al., 2015, 2016a,b, 2018; Rustagi et al., 2015; Tak et al., 2017; Xu et al., 2020). These previous studies suggest that banana plants with improved architecture can be developed using genetic strategies.

Recently, proponents of "the second Green Revolution" suggested that the development of crops with IPA would increase crop yield (Jiao et al., 2010). Previous studies in rice and maize have identified several genes that play important roles in increasing grain yield by shaping plant architecture, such as IPA1, TAC1, and UPA2 (Jiao et al., 2010; Ku et al., 2011; Dong et al., 2016; Wang B. et al., 2018; Hake and Richardson, 2019; Tian et al., 2019). On banana plantations, cultivars are often planted close together to increase production; as a consequence, banana plants receive insufficient light. Meanwhile, most cultivars have shallow root systems that are susceptible to drought (Dash and Rai, 2016). Therefore, IPA bananas should express a dwarf phenotype, with strong stems, more upright leaves, and a deep root system. Such plants would use light and water more efficiently, have higher lodging resistance, and thus, improved fruit yield.

The banana germplasm contains various valuable genes associated with useful agronomic traits such as height, leaf angle, root distribution, and resistance to abiotic and biotic stresses (Heslop-Harrison and Schwarzacher, 2007). For example, the banana B-genome has long been a target of breeding programs, as these bananas have a high tolerance of abiotic stresses, such as drought (Tripathi et al., 2019). Banana plants are susceptible to drought owing to their shallow roots, large size, and rapid growth (Nansamba et al., 2020). An optimal deep-rooting system may help bananas to resist drought stress by obtaining enough water from deep soil layers (Uga et al., 2011). Thus, studies of the connection between root system architecture and drought tolerance in B-genome bananas might help us to improve drought tolerance in bananas. Conventional gene mapping technologies cannot be used in bananas due to their sterility (Michael and Abdou, 2011). Therefore, genome-wide association studies (GWASs) may help to identify candidate genes associated with desirable traits (Nordborg and Weigel, 2008). GWASs can be used to comprehensively analyze the genomes and phenotypes associated with important agronomic traits (e.g., plant height, leaf angle, and root angle), and to identify the candidate genes underlying these traits (Nordborg and Weigel, 2008).

\section{THE CORRELATION BETWEEN PLANT PRODUCTION AND DISEASE RESISTANCE}

The balance between crop production and disease resistance is a major challenge facing modern agriculture (Wang J. et al., 2018). In some cases, the expression of genes associated with increased crop production decreased crop resistance to various pathogens, while the expression of genes improving pathogen resistance decreased crop yield and led to the development of 
other undesirable agricultural traits during the immune response (Wang J. et al., 2018). Ideal crop varieties should not only have high yields, but also high disease resistance during cultivation (Xu et al., 2017; Wang J. et al., 2018). Recently, several genes have been identified that might improve both crop yield and disease resistance. First, the Ideal Plant Architecture 1 (IPA1) gene, which encodes a squamosa promoter binding protein-like 14 (SPL14) transcription factor, binds to the promoter of the yield-related genes, increasing plant growth and yield (Wang J. et al., 2018). However, upon pathogen infection, IPA1 is phosphorylated at amino acid Ser163 and instead binds the promoter of WRKY DNA binding protein 45 (WRKY45), which enhances immunity to Magnaporthe oryzae; at $48 \mathrm{~h}$ after $M$. oryzae infection, IPA1 returns to its non-phosphorylated state, re-activating yieldrelated genes to continue to enhance growth and yield (Wang J. et al., 2018). Second, the Fusarium head blight 7 (Fhb7) gene in wheat mediated broad resistance to both Fusarium head blight and crown rot without decreasing wheat yield (Wang $\mathrm{H}$. et al., 2020). Third, transgenic crops with increased resistance to pathogens without decreased fitness have been developed using a TL1-binding transcription factor 1 (TBF1) cassette, which contains the immunity-inducible $T B F 1$ promoter and two pathogen-responsive upstream open reading frames (uORFs) of the TBF1 gene; this cassette mediates translational control of the expression levels of plants' own defense genes (Xu et al., 2017).

Similarly, banana breeders must also develop methods by which to control Fusarium wilt while also increasing, or at least not decreasing, yield. During propagation, some somatic clonal variants have been selected based on their Foc-resistant characteristics. For example, Foc-resistant GCTCV clones, which have excellent agronomic qualities and are Foc resistant, were derived from somaconal variants of the Giant Cavendish banana variety (Hwang and Ko, 2004). Some banana varieties, such as FHIA-01 (popularly known as Gold Finger) and Fenza 1, have also been developed for Foc resistance, high yield, and unique fruit taste using conventional cross-breeding (Hwang and Ko, 2004; Liu et al., 2012; Smith et al., 2014). However, despite the various breeding programs utilizing beneficial chemical and physical mutations, the number of Foc-resistant banana varieties remains limited at present. It is possible that transgenic methods and breeding programs will become important for the development for Foc-resistant banana cultivars.

In addition to the previously described genes from rice and wheat that confer both high yield and improved immunity and that can be expressed in bananas using genetic engineering techniques, we should also aim to identify native banana genes that are associated with both excellent immunity and high yield. There are over 1,000 banana cultivars and 180 wild banana species worldwide, representing a wide phenotypic and genomic diversity (Heslop-Harrison and Schwarzacher, 2007). However, due to the genetic sterility of bananas, it is difficult to identify candidate genes associated with desired features via forward genetic methods, such as genetic segregation tests. A re-sequencing dataset generated from five triploid bananas and four diploid bananas contained a total of 18.5 million single-nucleotide polymorphisms (SNPs), 1.4 million small insertions and deletions, and 0.2 million structural variations
(Wang et al., 2019). Due to the apparent abundant genetic diversity of polyploid bananas, GWAS is one of the best ways to discover genes and genetic variants related to relevant agronomic traits, as this method identifies statistically important associations between genomic DNA variations in various accessions and target agronomic traits (Zhou and Huang, 2018). In combination, transcriptome analysis, proteome analysis, metabolic profiling, and genomic data can be used to dissect target genes and illustrate the molecular mechanisms underlying the associated agronomic traits (Zhu et al., 2018). Recently, the CRISPR genome-editing system has emerged as a powerful tool for studies of gene function and crop breeding (Feng et al., 2013; Lu et al., 2017). The target specificity of CRISPR is high due to its utilization of short guide RNAs (sgRNAs) (Feng et al., 2013). Therefore, several CRISPR/Cas9-based mutagenesis approaches have been developed for genome-wide mutation screens in mammalian cells and rice using large-scale libraries of synthesized sgRNA (Shalem et al., 2014; Wang et al., 2014; Lu et al., 2017). Using the complete banana genome and the developed ECS methods, whole-genome CRISPR/Cas9 mutant libraries can be constructed for target gene mining, functional gene analysis, and genetic improvement in bananas. In the future, a combination of functional genomic and genetic transformation techniques may lead to the development of improved banana varieties, with both excellent disease resistance and high yield.

\section{METHODS OF GENETIC TRANSFORMATION}

Banana breeding programs generally aim to improve disease resistance, stress tolerance, yield, and plant architecture (Dash and Rai, 2016). Because conventional breeding is seriously hampered by banana sterility and polyploidy, molecular breeding provides a practical and effective means of genetic improvement (Michael and Abdou, 2011). Two important aspects of banana molecular breeding are efficient regeneration and genetic transformation (May et al., 1995). In vitro banana cultures have been developed using various explants, such as shoot tips (Matheka et al., 2019), immature male flowers (Jalil et al., 2003), apical meristems (Novak et al., 1989), corms (May et al., 1995), floral apices (Liu et al., 2016), and ECS (Vuylsteke and Langhe, 1985; Sági et al., 1995; Cote et al., 1996, 2000). Bananas are typically genetically transformed using particle bombardment or Agrobacterium-mediated transformation (May et al., 1995; Sági et al., 1995). Previous studies aiming to develop highly efficient, rapid, reproducible, and widely applicable systems for banana genetic transformation and regeneration have used a variety of explant types, banana genotypes, transformation methods, transformation protocols, transformation vectors, and transformation promoters (Table 2). However, even though several varieties of bananas have been genetically transformed and regenerated, the developed methods are variety dependent (Tripathi et al., 2019). Thus, an efficient, stable transformation and regeneration protocol that is applicable to all banana varieties is urgently needed. 
TABLE 2 | Genetic transformations of bananas.

\begin{tabular}{|c|c|c|c|c|c|c|c|}
\hline Genotype & Explant tissue & Agrobacterium strain & Promoter & Plasmid & Transformed gene & $\begin{array}{l}\text { Transformation } \\
\text { efficiency }\end{array}$ & References \\
\hline $\begin{array}{l}\text { SH } 3362 \text { (AA), Grand Nain } \\
\text { (AAA), Cardaba (ABB), } \\
\text { Bodadillo (AA) }\end{array}$ & $\begin{array}{l}\text { Leaf sheaths and corm } \\
\text { tissues from the apical } \\
\text { meristem }\end{array}$ & - & - & - & - & - & Novak et al. (1989) \\
\hline $\begin{array}{l}\text { Grand Naine (AAA), Yangambi } \\
\text { (AAA), French Plantain (AAB), } \\
\text { Mysore (AAB), Silk (AAB), } \\
\text { Pelipita (ABB) }\end{array}$ & $\begin{array}{l}\text { ESC from immature male } \\
\text { flowers }\end{array}$ & - & - & - & - & - & Escalant et al. (1994) \\
\hline Bluggoe (ABB) & Protoplasts & electroporation & CaMV35S, 2 × CaMV35S & pBI221, pBI426, pB|505 & vidA & $\begin{array}{l}\text { Transient expression } \\
\text { efficiency is up to } 1.8 \%\end{array}$ & Sági et al. (1994) \\
\hline $\begin{array}{l}\text { Bluggoe (ABB), Williams } \\
\text { (AAA), Three Hand Planty } \\
\text { (AAB) }\end{array}$ & $\begin{array}{l}\text { ESC from proliferating } \\
\text { shoot tip buds }\end{array}$ & Particle bombardment & $2 \times$ CaMV35S, pEmu, pUbi & $\begin{array}{l}\text { pWRG1515, pBI221, pBI426, } \\
\text { pBI505, pAHC27, pEmuGN }\end{array}$ & uidA & 25 plants & Sági et al. (1995) \\
\hline Grand Nain (AAA) & $\mathrm{AM}, \mathrm{CS}$ & $\begin{array}{l}\text { Particle bombardment and } \\
\text { LBA4404 }\end{array}$ & OsActin 1 & pBl141 & Nptll, uidA & Up to $50 \%$, & May et al. (1995) \\
\hline Grand Nain (AAA) & $\begin{array}{l}\text { ESC from immature male } \\
\text { flowers }\end{array}$ & Particle bombardment & Ubi-1, pBT6.3, CaMV35S & 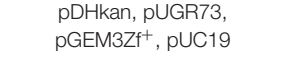 & $\begin{array}{l}\text { ORF of BBTV DNA-1, ORF } \\
\text { of BBTV DNA-5, nptll, uidA }\end{array}$ & $11 \%$ & Becker et al. (2000) \\
\hline Rasthali (AAB) & ECS from shoot-tips & EHA105 & Gelvin & pVGSUN & uidA/int & $\begin{array}{l}40 \text { independently } \\
\text { transformed plants per } \\
0.5 \mathrm{~mL} \text { packed cell } \\
\text { volume }\end{array}$ & Ganapathi et al. (2001) \\
\hline $\begin{array}{l}\text { Grand Nain (AAA), Lady } \\
\text { Finger (AAB) }\end{array}$ & $\begin{array}{l}\text { ECS From immature male } \\
\text { flowers }\end{array}$ & AGL1, LBA4404 & CaMV35s & $\begin{array}{l}\text { pCAMBIA1305.1, pART-Test7 } \\
\text { (electroporation) }\end{array}$ & uidA, GFP & $\begin{array}{l}\text { Up to } 65 \text { plants per } \\
50 \text { mg of settled cell } \\
\text { volume of ESC }\end{array}$ & Khanna et al. (2004) \\
\hline Williams (AAA) & $\begin{array}{l}\text { ECS from highly } \\
\text { proliferating meristematic } \\
\text { tissues }\end{array}$ & - & - & - & - & - & Chun et al. (2005) \\
\hline Musa acuminata cv. Mas (AA) & $\begin{array}{l}\text { ECS from immature male } \\
\text { flowers }\end{array}$ & EHA105 & CaMV35s & pCAMBIA2301 & uidA/int & $\begin{array}{c}490 \text { transgenic plants per } \\
0.5 \mathrm{~mL} \text { PCV of ECS were } \\
\text { obtained }\end{array}$ & Huang et al. (2007) \\
\hline Rasthali (AAB) & 3 months old sucker & $\begin{array}{l}\text { EHA105, EHA101, } \\
\text { LBA4404, (sonicated and } \\
\text { vacuum infiltered) }\end{array}$ & CaMV35S & pCAMBIA1301 & uidA & $39.4 \pm 0.5 \%$ & $\begin{array}{l}\text { Subramanyam et al. } \\
\text { (2011) }\end{array}$ \\
\hline Gonja manjaya (AAB) & $\begin{array}{l}\text { ECS from highly } \\
\text { proliferative multiple buds }\end{array}$ & EHA105 & CaMV35S & pBl121 & uidA & $\begin{array}{c}50-60 \text { transgenic plants } \\
\text { per } 0.5 \mathrm{~mL} \text { settled cell } \\
\text { volume }\end{array}$ & Tripathi et al. (2012) \\
\hline Grand Naine (AAA) & $\begin{array}{l}\text { ECS from immature male } \\
\text { flowers }\end{array}$ & EHA105 & pGmHSP17.6-L, pAtHSP18.2 & pGW-A & $\begin{array}{l}\text { Cre/lox recombination } \\
\text { system }\end{array}$ & $\begin{array}{l}702(41 \%), 379(29 \%) \\
\text { regenerated plants }\end{array}$ & $\begin{array}{l}\text { Chong-Pérez et al. } \\
\text { (2012) }\end{array}$ \\
\hline Grand Naine (AAA) & $\begin{array}{l}\text { ECS from immature male } \\
\text { flowers }\end{array}$ & EHA105 & pOsREG-2 & pGW-A & $\begin{array}{l}\text { Cre/lox recombination } \\
\text { system }\end{array}$ & $\begin{array}{l}\text { Up to } 76 \% \text { embryo } \\
\text { colonies per plate }\end{array}$ & $\begin{array}{l}\text { Chong-Pérez et al. } \\
\text { (2013) }\end{array}$ \\
\hline Williams (AAA) & $\begin{array}{l}\text { Stable GUS-expressing } \\
\text { ECS }\end{array}$ & EHA105 & pZmUbi & PSTARGATE & gusA $A^{I N T}$ & $\begin{array}{l}\text { Up to } 100 \text { independent } \\
\text { transgenic lines }\end{array}$ & Dang et al. (2014) \\
\hline $\begin{array}{l}\text { Baxi (AAA), Gongjiao (AA), } \\
\text { Red banana (AAA), Rose } \\
\text { banana (AA), Xinglongnaijiao } \\
\text { (AAB) }\end{array}$ & $\begin{array}{l}\text { Thin cell layers from shoot } \\
\text { tips }\end{array}$ & $\begin{array}{l}\text { pCAS04/AGL } 1+\text { particle } \\
\text { bombardment }\end{array}$ & Zmubi & pCASO4 & $\begin{array}{l}\text { Notll, uidA without } \\
\text { promoter }\end{array}$ & $4.33 \%-9.81 \%$ & Liu et al. (2016) \\
\hline Gros Michel (AAA) & $\begin{array}{l}\text { ECS from the immature } \\
\text { male inflorescence }\end{array}$ & EHA105 & OsU6a, OsU3 & pYLCRISPR/Cas9Pubi-H & sgRNA of MaGA200x2 & $\begin{array}{l}152 \text { independent } \\
\text { transgenic lines }\end{array}$ & Shao et al. (2019) \\
\hline Tai-chiao No.7 (AAA) & Plantlets & EHA105 & CaMV35S & pJL89 & MaPDS, MaGSA & $95 \%$ efficiency & Tzean et al. (2019) \\
\hline $\begin{array}{l}\text { Ensete ventricosum cv. } \\
\text { Bedadeti }\end{array}$ & Multiple buds & EHA105 or LBA4404 & CaMV35S & pCAMBIA2300 & GFP & $1.25 \%$ & Matheka et al. (2019) \\
\hline $\begin{array}{l}\text { Williams (AAA), Grand Naine } \\
\text { (AAA) }\end{array}$ & $\begin{array}{l}\text { ECS from immature male } \\
\text { flowers }\end{array}$ & LBA4404, AGL1 & CaMV35S & pMF1 & Recombinase- $L B D$ gene & $\begin{array}{l}\text { Up to } 30 \text { transgenic } \\
\text { plants }\end{array}$ & Kleidon et al. (2020) \\
\hline
\end{tabular}

ORF, open reading frame:

Npt, neomycin phosphotransferase;

AM, apical meristem;

CS, corm slices;

gusA/int, $\beta$-glucuronidase gene containing its intron;

PCV, packed cell volume. 
During banana genetic transformation, regeneration is generally performed via organogenesis based on meristemic tissue, or via somatic embryogenesis based on ECS (Novak et al., 1989; May et al., 1995). Meristematic tissues, such as shoot tips and floral apices, are widely used as explants for clonal propagation and transformation due to their rapid regeneration times (May et al., 1995; Liu et al., 2016). Although the applicability of this system is limited due to its unavoidable generation of chimeras, it has been shown that two or more cycles of meristem development generated plants with no chimeric tissues (May et al., 1995). To date, the most efficient regeneration and transformation system using longitudinal bud sections as explants was developed by Liu et al. (2016); this system was successfully applied to five banana cultivars: Gongjiao (AA), Red banana (AAA), Rose Banana (AA), Baxi (AAA), and Xinglongnaijiao (ABB) (Liu et al., 2016). In contrast to meristematic tissues, ECSs are an ideal explant for banana genetic transformation, because transgenic plants are derived from a single cell, avoiding the risk of chimeras (Sági et al., 1995). Although the establishment and regeneration of an ECS is timeconsuming and inefficient (Novak et al., 1989; Tripathi et al., 2015), ECSs have been successfully obtained from basal leaf sheaths and corm tissues (Novak et al., 1989), highly proliferative meristematic tissue (Chun et al., 2005; Strosse et al., 2006), and immature male flowers (Cote et al., 1996; Dale et al., 2017). Once developed, ECSs can be maintained for 1-1.5 years, although regeneration capacity declines with time (Tripathi et al., 2015). Becker et al. (2000) found that, in Grand Nain bananas, 6 months old embryogenic cells had the greatest regenerative capacity.

\section{GENE EDITING SYSTEMS}

With the publication of the banana genome and the development of feasible genetic transformation methods, gene editing systems, such as host-induced gene silencing (HIGS) and CRISPR, have become increasingly used to mutate specific genes, leading to the production of mutant plants without having to insert foreign genes (Tripathi et al., 2019; Wang and Chen, 2020).

HIGS has been widely used to develop disease-resistant crops by targeting specific important fungal genes (Huang et al., 2006; Mao et al., 2007). For example, transgenic banana plants carrying small interfering RNA (siRNA) targeting the Foc velvet and Fusarium transcription factor 1 ( $f t f 1$ ) genes sustainably resisted Foc Race 1 under glasshouse conditions (Ghag et al., 2014). Similarly, transgenic bananas designed to silence the expression of the TR4 ergosterol biosynthesis genes ERG6 and ERG11 exhibited significantly improved resistance to TR4 (Dou et al., 2019).

However, the success of HIGS techniques against Foc is largely determined by the selection of appropriate target Foc-derived genes (Dou et al., 2019). Studies of the Foc infection process have identified many key pathogenesis genes in F. oxysporum (Li M. et al., 2019). For example, two mitogen-activated protein kinase genes (MAPKs) in F. oxysporum, Fmk1 and Mpk1, are associated with cell wall integrity and virulence; the expression of these genes affected the ability of Foc to recognize and attach to tomato roots (Segorbe et al., 2017). During F. oxysporum invasion and colonization, the sucrose non-fermenting1 (SNF1) protein kinase gene regulates the expression of cell wall degrading enzymes (CWDEs) and virulence of F. oxysporum (Islam et al., 2017). After infection, a number of virulent $F$. oxysporum toxins lead to the development of disease symptoms in the host; these toxins include effector proteins, which are encoded by the secreted into xylem (SIX) genes (Widinugraheni et al., 2018), and fusaric acid (FA), which is encoded by a cluster of FA biosynthetic genes (Ding et al., 2018). However, almost all of these pathogenic mechanisms have been described in Fusarium strains specialized to hosts other than bananas, such as Fusarium oxysporum f. sp. lycopersici (Li M. et al., 2019). Because Foc is strictly host-specialized, we should aim to investigate banana-specific pathogenic and infectious mechanisms in Foc. This work will help us to design better targets for the effective control of Fusarium wilt in bananas.

The recently developed precise gene-editing tool CRISPR may be useful for the highly accurate introduction of beneficial genes into the banana, without the concomitant introduction of undesirable foreign genes. The CRISPR genome-editing system includes two key components: an sgRNA that specifically recognizes the target DNA, and a Cas9 endonuclease that precisely cleaves the target DNA (Feng et al., 2013). The most significant advantages of the CRISPR system are twofold: multiple simultaneous mutations and Cas9-free plants (Wang and Chen, 2020). Cas-free transgenic plants are more acceptable to consumers because no foreign genes have been inserted (Maxmen, 2019). In addition, the prolonged presence of Cas9 in a plant might generate off-target mutations. Traditional PCR-based methods and recent fluorescence-based methods for obtaining Cas9-free transgenic plants are based on genetic segregation in sexually propagated plants (Gao et al., 2016; Yu and Zhao, 2019; Wang and Chen, 2020). However, such methods are not applicable in asexually propagated plants like bananas. To solve this problem, preassembled Cas9 proteingRNA ribonucleoproteins (RNPs), rather than the plasmids that encode these components, are delivered into asexually propagated plant cells (Woo et al., 2015). These RNPs cleave target sites immediately after transfection, and are then rapidly degraded by endogenous proteases in the cell. In this way, targeted mutagenesis in Cas-free regenerated plants is achieved (Woo et al., 2015). Several groups are attempting to improve TR4 resistance in Cavendish bananas using CRISPR, not only by suppressing the expression of the TR4 susceptible gene, but also by expressing dormant genes conferring TR4 resistance (Dale et al., 2017; Maxmen, 2019). The CRISPR system has also been used to develop a semi-dwarf phenotype of the Gros Michel banana cultivar (Shao et al., 2019).

Virus-induced gene silencing (VIGS) can be used to analyze gene function via the transient silencing of RNA expression; VIGS thus compensates for the time-consuming and inefficient nature of transgenic banana production (Baulcombe, 1999). For example, Tzean et al. (2019) developed a VIGS system based on a banana-infecting cucumber mosaic virus (CMV) to efficiently silence target genes. This system might be useful for gene functional analysis in bananas before stable genetic transformation. In summary, the application of various 
genome editing systems may lead to banana germplasm innovation and additional functional genomics studies of various agricultural traits.

\section{CHALLENGES AND FUTURE POSSIBILITIES FOR THE DEVELOPMENT OF BANANA CULTIVARS WITH FUSARIUM WILT RESISTANCE AND IDEAL PLANT ARCHITECTURE}

Bananas are the fourth most important crop in developing countries after rice, wheat, and maize; these crops are important for food security (Dash and Rai, 2016). The most destructive threat to banana production is Panama disease, caused by Foc. Because Fusarium cannot be controlled by any chemical or physical means once established, sustainable banana production requires the use of Foc-resistant varieties (Heslop-Harrison and Schwarzacher, 2007). In addition to disease resistance, banana production can also be improved by the development of bananas with IPA (Khush, 2001; Wang et al., 2017). Banana plants with ideal architecture (e.g., dwarfism, strong stems, more upright leaves, and root systems with excellent hydrotropism) would have improved light and water utilization efficiency, lodging resistance, yield, and disease resistance under the current dense planting schemes (Dash and Rai, 2016; Wang J. et al., 2018). It is extremely difficult to develop new banana varieties by conventional breeding methods, due to the sterility, polyploidy, and parthenocarpy of most banana cultivars (Michael and Abdou, 2011). Genetic modification, which compensates for the lack of traditional breeding opportunities, is an effective way to develop bananas with improved agronomic traits, such as increased disease resistance and yield.

Two major challenges face banana breeders aiming to produce genetically modified banana varieties with Foc resistance and no yield penalty. First, genes associated with Foc resistance, as well as with other important agronomic traits, must be identified, functionally assessed, and utilized in target breeding programs. For example, we should aim to characterize the genes that play a role in Foc resistance and ideal plant architecture, such as the specific receptors of effector proteins like SIX, and the genes involved in abiotic resistance. Second, a highly efficient, stable transformation and regeneration system must be developed. The genetic transformation methods available at present are variety dependent, and the regeneration of complete plants from a single transformed cell is difficult (Tripathi et al., 2019).

Functional genomic studies of the $M$. acuminate and M. balbisiana genomes will help to clarify the molecular

\section{REFERENCES}

Baulcombe, D. C. (1999). Fast forward genetics based on virus-induced gene silencing. Curr. Opin. Plant Biol. 2, 109-113. doi: 10.1016/s1369-5266(99) 80022-3

Becker, D. K., Dugdale, B., Smith, M. K., Harding, R. M., and Dale, J. L. (2000). Genetic transformation of Cavendish banana (Musa spp. AAA group) cV mechanisms underlying the banana immune response, as well as to determine the correlations between disease resistance and banana yield at the genomic level, and to identify the genes associated with pathogen resistance and ideal plant architecture, which can be used for targeted breeding (D'Hont et al., 2012; Wang et al., 2019). In addition, among the Musa germplasms are many cultivars and wild species with various agronomic traits, which represent a valuable gene pool resource for banana improvement (HeslopHarrison and Schwarzacher, 2007). The rapid increase in our understanding of Musa genomics, and the development of associated technologies, may help us to better leverage Musa biodiversity in targeted molecular breeding programs. Furthermore, due to the host specificity of Foc (Swarupa et al., 2014), it is important to investigate its bananaspecific pathogenic and infectious mechanisms. An improved understanding of these mechanisms will help us to design siRNAs targeting specific key pathogenic genes and then to use the HIGS system to develop disease-resistant bananas. Finally, once the molecular mechanisms are better understood, genetic engineering techniques, such as precise genome editing, can be used effectively to develop genetically engineered elite banana cultivars with improved disease resistance, ideal architecture, and increased production.

\section{AUTHOR CONTRIBUTIONS}

$\mathrm{XW}, \mathrm{RY}$, and JL conceived, designed the work, and wrote the manuscript. All authors contributed to the article and approved the submitted version.

\section{FUNDING}

This review was supported by the earmarked fund for the Belt and Road Tropical Project (BARTP-07), the earmarked fund for China Agriculture Research System (CARS-31-02), and the Agricultural Science and Technology Innovation Program of CAAS "Evaluation and Regulation of Nutritional Quality of Major Agricultural Products" (CAAS-XTCX20190025-4).

\section{ACKNOWLEDGMENTS}

We thank LetPub (www.letpub.com) for its linguistic assistance and scientific consultation during the preparation of this manuscript.

'Grand Nain' via microprojectile bombardment. Plant Cell Rep. 19, 229-234. doi: $10.1007 /$ s002990050004

Chakrabarti, A., Ganapathi, T. R., Mukherjee, P. K., and Bapat, V. A. (2003). MSI99, a magainin analogue, imparts enhanced disease resistance in transgenic tobacco and banana. Planta 216, 587-596. doi: 10.1007/s00425-002-0918-y

Chen, J., Xie, J., Duan, Y., Hu, H., Hu, Y., and Li, W. (2016). Genomewide identification and expression profiling reveal tissue-specific expression 
and differentially-regulated genes involved in gibberellin metabolism between Williams banana and its dwarf mutant. BMC Plant Biol. 16:123. doi: 10.1186/ s12870-016-0809-1

Chhikara, S., Chaudhury, D., Dhankher, O. P., and Jaiwal, P. K. (2012). Combined expression of a barley class II chitinase and type I ribosome inactivating protein in transgenic Brassica juncea provides protection against Alternaria brassicae. Plant Cell Tissue Organ. Cult. 108, 83-89. doi: 10.1007/s11240-011-0015-7

Chong-Pérez, B., Kosky, R. G., Reyes, M., Rojas, L., Ocaña, B., Tejeda, M., et al. (2012). Heat shock induced excision of selectable marker genes in transgenic banana by the Cre-lox site-specific recombination system. J. Biotechnol. 159, 265-273. doi: 10.1016/j.jbiotec.2011.07.031

Chong-Pérez, B., Reyes, M., Rojas, L., Ocaña, B., Ramos, A., Kosky, R. G., et al. (2013). Excision of a selectable marker gene in transgenic banana using a Cre/lox system controlled by an embryo specific promoter. Plant Mol. Biol. 83, 143-152. doi: 10.1007/s11103-013-0058-8

Chun, X., Panis, B., Strosse, H., Hua, P., Huo, G., Huai, Z., et al. (2005). Establisment of embryogenic cell suspension and plant regeneration of the dessert banana "Williams" (Musa AAA group). J. Hortic. Sci. Biotechnol. 80, 523-528. doi: 10.1080/14620316.2005.11511972

Cote, F., Domergue, R., Monmarson, S., Schwendiman, J., Teisson, C., and Escalant, J. (1996). Embryogenic cell suspensions from the male flower of $M u s a$ AAA cv. Grand Nain. Physiol. Plant 97, 285-290. doi: 10.1034/j.1399-3054. 1996.970211.x

Cote, F., Goue, O., Domergue, R., Panis, B., and Jenny, C. (2000). In-field behaviour of banana plants (Musa AA sp) obtained after regeneration of cryopreserved embryogenic cell suspensions. CryoLetters 21, 19-24.

D’Hont, A., Denoeud, F., Aury, J.-M., Baurens, F.-C., Carreel, F., Garsmeur, O., et al. (2012). The banana (Musa acuminata) genome and the evolution of monocotyledonous plants. Nature 488, 213-217. doi: 10.1038/nature11241

Dale, J., James, A., Paul, J. Y., Khanna, H., and Smith, M. (2017). Transgenic Cavendish bananas with resistance to Fusarium wilt tropical race 4 . Nat. Commun. 8, 1-8.

Dang, T. V., Windelinckx, S., Henry, I. M., De Coninck, B., Cammue, B. P., Swennen, R., et al. (2014). Assessment of RNAi-induced silencing in banana (Musa spp.). BMC Res. Notes 7:655. doi: 10.1186/1756-0500-7-655

Das, D. K., and Rahman, A. (2012). RETRACTED ARTICLE: Expression of a rice chitinase gene enhances antifungal response in transgenic litchi (cv. Bedana). Plant Cell Tissue Organ. Cult. 109, 315-325. doi: 10.1007/s11240-011-0097-2

Dash, P., and Rai, R. (2016). Translating the "Banana Genome" to Delineate Stress Resistance, Dwarfing, Parthenocarpy and Mechanisms of Fruit Ripening. Front. Plant Sci. 7:1543. doi: 10.3389/fpls.2016.01543

Ding, Z., Yang, L., Wang, G., Guo, L., Liu, L., Wang, J., et al. (2018). Fusaric acid is a virulence factor of Fusarium oxysporum $\mathrm{f}$. sp. cubense on banana plantlets. Trop. Plant Pathol. 43, 297-305. doi: 10.1007/s40858-018-0230-4

Dita, M., Barquero, M., Heck, D., Mizubuti, E. S. G., and Staver, C. P. (2018). Fusarium Wilt of Banana: Current Knowledge on Epidemiology and Research Needs Toward Sustainable Disease Management. Front. Plant Sci. 9:1468. doi: 10.3389/fpls.2018.01468

Dong, H., Zhao, H., Xie, W., Han, Z., Li, G., Yao, W., et al. (2016). A Novel Tiller Angle Gene, TAC3, together with TAC1 and D2 Largely Determine the Natural Variation of Tiller Angle in Rice Cultivars. PLoS Genet. 12:e1006412. doi: 10.1371/journal.pgen.1006412

Dou, T., Shao, X., Hu, C., Liu, S., Sheng, O., Bi, F., et al. (2019). Host-induced gene silencing of Foc TR4 ERG6/11 genes exhibits superior resistance to Fusarium wilt of banana. Plant Biotechnol. J. 18, 11-13. doi: 10.1111/pbi.13204

Escalant, J. -V., Teisson, C., and Cote, F. (1994). Amplified somatic embryogenesis from male flowers of triploid banana and plantain cultivars (Musa spp.). In Vitro Cell. Dev. Biol. Plant 30, 181-186. doi: 10.1007/BF02823029

Feng, Z., Zhang, B., Ding, W., Liu, X., Yang, D.-L., Wei, P., et al. (2013). Efficient genome editing in plants using a CRISPR/Cas system. Cell Res. 23, 1229-1232. doi: $10.1038 / \mathrm{cr} .2013 .114$

Fu, Z. Q., and Dong, X. (2013). Systemic acquired resistance: turning local infection into global defense. Annu. Rev. Plant Biol. 64, 839-863. doi: 10.1146/annurevarplant-042811-105606

Ganapathi, T. R., Higgs, N. S., Balint-Kurti, P. J., Arntzen, C. J., May, G. D., Van Eck, J. M., et al. (2001). Agrobacterium-mediated transformation of embryogenic cell suspensions of the banana cultivar Rasthali (AAB). Plant Cell Rep. 20, 157-162. doi: 10.1007/s002990000287
Gao, C., Xu, H., Huang, J., Sun, B., Zhang, F., Savage, Z., et al. (2020). Pathogen manipulation of chloroplast function triggers a light-dependent immune recognition. Proc. Natl. Acad. Sci. U. S. A. 117, 9613-9620. doi: 10.1073/pnas. 2002759117

Gao, X., Chen, J., Dai, X., Zhang, D., and Zhao, Y. (2016). An Effective Strategy for Reliably Isolating Heritable and Cas9-Free Arabidopsis Mutants Generated by CRISPR/Cas9-Mediated Genome Editing. Plant Physiol. 171, 1794-1800. doi: $10.1104 /$ pp.16.00663

Ghag, S. B., Shekhawat, U. K., and Ganapathi, T. R. (2012). Petunia floral defensins with unique prodomains as novel candidates for development of fusarium wilt resistance in transgenic banana plants. PLoS One 7:e39557. doi: 10.1371/journal. pone.0039557

Ghag, S. B., Shekhawat, U. K., and Ganapathi, T. R. (2014). Host-induced posttranscriptional hairpin RNA-mediated gene silencing of vital fungal genes confers efficient resistance against Fusarium wilt in banana. Plant Biotechnol. J. 12, 541-553. doi: 10.1111/pbi.12158

Girhepuje, P. V., and Shinde, G. B. (2011). Transgenic tomato plants expressing a wheat endochitinase gene demonstrate enhanced resistance to Fusarium oxysporum f. sp. lycopersici. Plant Cell Tissue Organ. Cult. 105, 243-251. doi: 10.1007/s11240-010-9859-5

Hake, S., and Richardson, A. (2019). Using wild relatives to improve maize. Science 365, 640-641. doi: 10.1126/science.aay5299

Heslop-Harrison, J. S., and Schwarzacher, T. (2007). Domestication, genomics and the future for banana. Ann. Bot. 100, 1073-1084. doi: 10.1093/aob/mcm191

Hu, C. H., Wei, H., Huang, D., and Yi, G. J. (2013). An efficient protocol for the production of chit42 transgenic Furenzhi banana (Musa spp. AA group) resistant to Fusarium oxysporum. Vitro Cell. Dev. Biol. Plant 49, 584-592. doi: 10.1007/s11627-013-9525-9

Huang, G., Allen, R., Davis, E. L., Baum, T. J., and Hussey, R. S. (2006). Engineering broad root-knot resistance in transgenic plants by RNAi silencing of a conserved and essential root-knot nematode parasitism gene. Proc. Natl. Acad. Sci. U. S. A. 103, 14302-14306. doi: 10.1073/pnas.060469 8103

Huang, X., Huang, X. -L., Xiao, W., Zhao, J. -T., Dai, X. -M., Chen, Y. -F., et al. (2007). Highly efficient Agrobacterium-mediated transformation of embryogenic cell suspensions of Musa acuminata cv. Mas (AA) via a liquid co-cultivation system. Plant Cell Rep. 26, 1755-1762. doi: 10.1007/s00299-0070376-x

Hwang, S. C., and Ko, W. H. (2004). Cavendish Banana Cultivars Resistant to Fusarium Wilt Acquired through Somaclonal Variation in Taiwan. Plant Dis. 88, 580-588. doi: 10.1094/pdis.2004.88.6.580

Islam, K. T., Bond, J. P., and Fakhoury, A. M. (2017). FvSNF1, the sucrose nonfermenting protein kinase gene of Fusarium virguliforme, is required for cellwall-degrading enzymes expression and sudden death syndrome development in soybean. Curr. Genet. 63, 723-738. doi: 10.1007/s00294-017-0676-9

Jalil, M., Khalid, N., and Othman, R. Y. (2003). Plant regeneration from embryogenic suspension cultures of Musa acuminata cv. Mas (AA). Plant Cell Tissue Organ. Cult. 75, 209-214.

Jiao, Y. Q., Wang, Y. H., Xue, D. W., Wang, J., and Li, J. Y. (2010). Regulation of OsSPL14 by OsmiR156 defines ideal plant architecture in rice. Nat. Genet. 42, 541-544. doi: 10.1038/ng.591

Khanna, H., Becker, D., Kleidon, J., and Dale, J. (2004). Centrifugation assisted Agrobacterium tumefaciens-mediated transformation (CAAT) of embryogenic cell suspensions of banana (Musa spp. Cavendish AAA and Lady finger AAB). Mol. Breed. 14, 239-252. doi: 10.1023/B:MOLB.0000047771.34186.e8

Khush, G. S. (2001). Green revolution: the way forward. Nat. Rev. Genet. 2, 815-822. doi: 10.1038/35093585

Kitomi, Y., Kanno, N., Kawai, S., Mizubayashi, T., Fukuoka, S., and Uga, Y. (2015). QTLs underlying natural variation of root growth angle among rice cultivars with the same functional allele of DEEPER ROOTING 1. Rice 8:16. doi: 10.1186/s12284-015-0049-2

Kleidon, J., Brinin, A., Paul, J.-Y., Harding, R., Dale, J., Dugdale, B., et al. (2020). Production of selectable marker gene-free Cavendish banana (Musa spp.) using a steroid-inducible recombinase platform. Transgenic Res. 29, 81-93. doi: 10. 1007/s11248-019-00179-6

Krishna, G., Singh, B. K., Kim, E. K., Morya, V. K., and Ramteke, P. W. (2015). Progress in genetic engineering of peanut (Arachis hypogaea L.)-a review. Plant Biotechnol. J. 13, 147-162. doi: 10.1111/pbi.12339 
Ku, L., Wei, X., Zhang, S., Zhang, J., Guo, S., and Chen, Y. (2011). Cloning and characterization of a putative TAC1 ortholog associated with leaf angle in maize (Zea mays L.). PLoS One 6:e20621. doi: 10.1371/journal.pone.0020 621

Langhe, E., Vrydaghs, L., de Maret, P., Perrier, X., and Denham, T. (2008). Why Bananas Matter: An introduction to the history of banana domestication. Ethnobot. Res. Appl. 7, 165-174. doi: 10.17348/era.7.0.165-177

Li, C. Y., Deng, G. M., Yang, J., Viljoen, A., Jin, Y., Kuang, R. B., et al. (2012). Transcriptome profiling of resistant and susceptible Cavendish banana roots following inoculation with Fusarium oxysporum f. sp. cubense tropical race 4. BMC Genom. 13:374. doi: 10.1186/1471-2164-13-374

Li, C., Shao, J., Wang, Y., Li, W., Guo, D., Yan, B., et al. (2013). Analysis of banana transcriptome and global gene expression profiles in banana roots in response to infection by race 1 and tropical race 4 of Fusarium oxysporum f. sp. cubense. BMC Genom. 14:851. doi: 10.1186/1471-2164-14-851

Li, M., Yuan, M., Jiang, Z., and Li, H. (2019). Research progress in pathogenic mechanism of Fusarium oxysporum f. sp. cubense. J. Fruit Sci. 36, 803-811.

Li, P., Wang, Y., Qian, Q., Fu, Z., Wang, M., Zeng, D., et al. (2007). LAZY1 controls rice shoot gravitropism through regulating polar auxin transport. Cell Res. 17, 402-410. doi: 10.1038/cr.2007.38

Li, W., Wang, X., Li, C., Sun, J., Li, S., and Peng, M. (2019). Dual species transcript profiling during the interaction between banana (Musa acuminata) and the fungal pathogen Fusarium oxysporum f. sp. cubense. BMC Genom. 20:519. doi: 10.1186/s12864-019-5902-z

Liu, J., Gao, P., Sun, X., Zhang, J., Sun, P., Wang, J., et al. (2016). Efficient regeneration and genetic transformation platform applicable to five Musa varieties. Electron. J. Biotechnol. 25, 33-38. doi: 10.1016/j.ejbt.2016.11.002

Liu, W., Li, F., and Huang, H. (2012). Introduction experiment and application assessment of two kinds of new banana cultivars resistant to Fusarium wilt. Guangdong Agricult. Sci. 24, 42-44.

Lu, Y., Ye, X., Guo, R., Huang, J., Wang, W., Tang, J., et al. (2017). Genome-wide Targeted Mutagenesis in Rice Using the CRISPR/Cas9 System. Mol. Plant 10, 1242-1245. doi: 10.1016/j.molp.2017.06.007

Mahdavi, F., Sariah, M., and Maziah, M. (2012). Expression of Rice ThaumatinLike Protein Gene in Transgenic Banana Plants Enhances Resistance to Fusarium Wilt. Appl. Biochem. Biotechnol. 166, 1008-1019. doi: 10.1007/ s12010-011-9489-3

Mao, Y. B., Cai, W. J., Wang, J. W., Hong, G. J., Tao, X. Y., Wang, L. J., et al. (2007). Silencing a cotton bollworm P450 monooxygenase gene by plant-mediated RNAi impairs larval tolerance of gossypol. Nat. Biotechnol. 25, 1307-1313. doi: $10.1038 /$ nbt1352

Matheka, J., Tripathi, J. N., Merga, I., Gebre, E., and Tripathi, L. (2019). A simple and rapid protocol for the genetic transformation of Ensete ventricosum. Plant Methods 15:130.

Maxmen, A. (2019). CRISPR might be the banana's only hope against a deadly fungus. Nature 574:15. doi: 10.1038/d41586-019-02770-7

May, G. D., Afza, R., Mason, H. S., Wiecko, A., Novak, F. J., and Arntzen, C. J. (1995). Generation of Transgenic Banana (Musa acuminata) Plants via Agrobacterium-Mediated Transformation. Bio. Technol. 13, 486-492. doi: 10. 1038/nbt0595-486

Maziah, M., Sariah, M., and Sreeramanan, S. (2007). Transgenic Banana Rastali (AAB) with $\beta$-1, 3-glucanase Gene for Tolerance to Fusarium Wilt Race 1 Disease via Agrobacterium-mediated Transformation System. Plant Pathol. J. 6, 271-282. doi: 10.3923/ppj.2007.271.282

Michael, P., and Abdou, T. (2011). Banana Breeding. London: Taylor \& Francis Group.

Nansamba, M., Sibiya, J., Tumuhimbise, R., Karamura, D., Kubiriba, J., and Karamura, E. (2020). Breeding banana (Musa spp.) for drought tolerance: A review. Plant Breed. 139, 685-696. doi: 10.1111/pbr.12812

Negi, S., Tak, H., and Ganapathi, T. R. (2015). Cloning and functional characterization of MusaVND1 using transgenic banana plants. Transgenic Res. 24, 571-585. doi: 10.1007/s11248-014-9860-6

Negi, S., Tak, H., and Ganapathi, T. R. (2016a). Expression analysis of MusaNAC68 transcription factor and its functional analysis by overexpression in transgenic banana plants. Plant Cell Tissue Organ. Cult. 125, 59-70. doi: 10.1007/s11240015-0929-6

Negi, S., Tak, H., and Ganapathi, T. R. (2016b). Functional characterization of secondary wall deposition regulating transcription factors MusaVND2 and
MusaVND3 in transgenic banana plants. Protoplasma 253, 431-446. doi: 10. 1007/s00709-015-0822-5

Negi, S., Tak, H., and Ganapathi, T. R. (2018). A banana NAC transcription factor (MusaSNAC1) impart drought tolerance by modulating stomatal closure and $\mathrm{H}_{2} \mathrm{O}_{2}$ content. Plant Mol. Biol. 96, 457-471. doi: 10.1007/s11103-018-0710-4

Nookaraju, A., and Agrawal, D. C. (2012). Enhanced tolerance of transgenic grapevines expressing chitinase and $\beta$-1,3-glucanase genes to downy mildew. Plant Cell Tissue Organ. Cult. 111, 15-28. doi: 10.1007/s11240-012-0166-1

Nordborg, M., and Weigel, D. (2008). Next-generation genetics in plants. Nature 456, 720-723. doi: 10.1038/nature07629

Novak, F. J., Afza, R., Van Duren, M., Perea-Dallos, M., Conger, B. V., and Tang, X. (1989). Somatic Embryogenesis and Plant Regeneration in Suspension Cultures of Dessert (AA and AAA) and Cooking (ABB) Bananas (Musa spp.). Biotechnology 7, 154-159. doi: 10.1038/nbt0289-154

Shalem, O., Sanjana, N. E., Hartenian, E., Shi, X., Scott, D. A., Mikkelson, T., et al. (2014). Genome-scale CRISPR-Cas9 knockout screening in human cells. Science 343, 85-87.

Subramanyam, K., Subramanyam, K., Sailaja, K. V., Srinivasulu, M., and Lakshmidevi, K. (2011). Highly efficient Agrobacterium-mediated transformation of banana $\mathrm{cv}$. Rasthali $(\mathrm{AAB})$ via sonication and vacuum infiltration. Plant Cell Rep. 30, 425-436. doi: 10.1007/s00299-010-0996-4

Paul, J. Y., Becker, D. K., Dickman, M. B., Harding, R. M., Khanna, H. K., and Dale, J. L. (2011). Apoptosis-related genes confer resistance to Fusarium wilt in transgenic 'Lady Finger' bananas. Plant Biotechnol. J. 9, 1141-1148. doi: 10.1111/j.1467-7652.2011.00639.x

Pegg, K. G., Coates, L. M., O’Neill, W. T., and Turner, D. W. (2019). The Epidemiology of Fusarium Wilt of Banana. Front. Plant Sci. 10:1395. doi: 10. 3389/fpls.2019.01395

Pei, X., Chen, S., Wen, R., Ye, S., Huang, J., Zhang, Y., et al. (2005). Creation of Transgenic Bananas Expressing Human Lysozyme Gene for Panama Wilt Resistance. J. Integr. Plant Biol. 47, 971-977. doi: 10.1111/j.1744-7909.2005. 00141.x

Ploetz, R. C. (2006). Fusarium Wilt of Banana Is Caused by Several Pathogens Referred to as Fusarium Oxysporum f. sp. cubense. Phytopathology 96:648.

Rustagi, A., Jain, S., Kumar, D., Shekhar, S., Jain, M., Bhat, V., et al. (2015). High Efficiency Transformation of Banana [Musa acuminata L. cv. Matti (AA)] for Enhanced Tolerance to Salt and Drought Stress Through Overexpression of a Peanut Salinity-Induced Pathogenesis-Related Class 10 Protein. Mol. Biotechnol. 57, 27-35. doi: 10.1007/s12033-014-9798-1

Sági, L., Panis, B., Remy, S., Schoofs, H., Smet, K. D., Swennen, R., et al. (1995). Genetic Transformation of Banana and Plantain (Musa spp.) via Particle Bombardment. BioTechnology 13, 481-485. doi: 10.1038/nbt0595-481

Sági, L., Remy, S., Panis, B., Swennen, R., and Volckaert, G. (1994). Transient gene expression in electroporated banana (Musa spp., cv. 'Bluggoe', ABB group) protoplasts isolated from regenerable embryogenetic cell suspensions. Plant Cell Rep. 13, 262-266. doi: 10.1007/bf00233316

Segorbe, D., Di Pietro, A., Pérez-Nadales, E., and Turrà, D. (2017). Three Fusarium oxysporum mitogen-activated protein kinases (MAPKs) have distinct and complementary roles in stress adaptation and cross-kingdom pathogenicity. Mol. Plant Pathol. 18, 912-924. doi: 10.1111/mpp.12446

Shao, X., Wu, S., Dou, T., Zhu, H., Hu, C., Huo, H., et al. (2019). Using CRISPR/Cas9 genome editing system to create MaGA20ox2 gene modified semi-dwarf banana. Plant Biotechnol. J. 18, 17-19. doi: 10.1111/pbi.13 216

Shekhawat, U. K. S., Ganapathi, T. R., and Srinivas, L. (2011a). Cloning and characterization of a novel stress-responsive WRKY transcription factor gene (MusaWRKY71) from Musa spp. cv. Karibale Monthan (ABB group) using transformed banana cells. Mol. Biol. Rep. 38, 4023-4035. doi: 10.1007/s11033010-0521-4

Shekhawat, U. K. S., Srinivas, L., and Ganapathi, T. R. (2011b). MusaDHN1, a novel multiple stress-inducible SK3-type dehydrin gene, contributes affirmatively to drought- and salt-stress tolerance in banana. Planta 234, 915932. doi: 10.1007/s00425-011-1455-3

Shekhawat, U. K., and Ganapathi, T. R. (2013). MusaWRKY71 overexpression in banana plants leads to altered abiotic and biotic stress responses. PLoS One 8:e75506. doi: 10.1371/journal.pone.0075506

Smith, M. K., Langdon, P. W., Pegg, K. G., and Daniells, J. W. (2014). Growth, yield and Fusarium wilt resistance of six FHIA tetraploid bananas (Musa spp.) 
grown in the Australian subtropics. Sci. Hortic. 170, 176-181. doi: 10.1016/j. scienta.2014.02.029

Song, S., Xu, Y., Huang, D., Miao, H., Liu, J., Jia, C., et al. (2018). Identification of a novel promoter from banana aquaporin family gene $(M a T I P 1 ; 2)$ which responses to drought and salt-stress in transgenic Arabidopsis thaliana. Plant Physiol. Biochem. 128, 163-169. doi: 10.1016/j.plaphy.2018.05.003

Sreedharan, S., Shekhawat, U. K. S., and Ganapathi, T. R. (2015). Constitutive and stress-inducible overexpression of a native aquaporin gene (MusaPIP2;6) in transgenic banana plants signals its pivotal role in salt tolerance. Plant Mol. Biol. 88, 41-52. doi: 10.1007/s11103-015-0305-2

Sreedharan, S., Shekhawat, U. K., and Ganapathi, T. R. (2012). MusaSAP1, a A20/AN1 zinc finger gene from banana functions as a positive regulator in different stress responses. Plant Mol. Biol. 80, 503-517. doi: 10.1007/s11103012-9964-4

Sreedharan, S., Shekhawat, U. K., and Ganapathi, T. R. (2013). Transgenic banana plants overexpressing a native plasma membrane aquaporin MusaPIP1;2 display high tolerance levels to different abiotic stresses. Plant Biotechnol. J. 11, 942-952. doi: 10.1111/pbi.12086

Stover, R. H., and Simmonds, N. W. (1987). Bananas. New York: Longman Scientific \& Technical (Wiley).

Strosse, H., Schoofs, H., Panis, B., Andre, E., Reyniers, K., and Swennen, R. (2006). Development of embryogenic cell suspensions from shoot meristematic tissue in bananas and plantains (Musa spp.). Plant Sci. 170, 104-112. doi: 10.1016/j. plantsci.2005.08.007

Sunisha, C., Sowmya, H. D., Usharani, T. R., Umesha, M., Gopalkrishna, H. R., and Saxena, A. (2020). Deployment of Stacked Antimicrobial Genes in Banana for Stable Tolerance Against Fusarium oxysporum f.sp. cubense Through Genetic Transformation. Mol. Biotechnol. 62, 8-17. doi: 10.1007/s12033-019-00 219-w

Swarupa, V., Ravishankar, K. V., and Rekha, A. (2014). Plant defense response against Fusarium oxysporum and strategies to develop tolerant genotypes in banana. Planta 239, 735-751. doi: 10.1007/s00425-013-2024-8

Tak, H., Negi, S., and Ganapathi, T. R. (2017). Banana NAC transcription factor MusaNACO42 is positively associated with drought and salinity tolerance. Protoplasma 254, 803-816. doi: 10.1007/s00709-016-0991-x

Tian, J., Wang, C., Xia, J., Wu, L., Xu, G., Wu, W., et al. (2019). Teosinte ligule allele narrows plant architecture and enhances high-density maize yields. Science 365:658. doi: 10.1126/science.aax5482

Tripathi, J. N., Muwonge, A., and Tripathi, L. (2012). Efficient regeneration and transformation of plantain cv. "Gonja manjaya" (Musa spp. AAB) using embryogenic cell suspensions. In Vitro Cell. Dev. Biol. Plant 48, 216-224. doi: 10.1007/s11627-011-9422-z

Tripathi, J. N., Oduor, R. O., and Tripathi, L. (2015). A High-Throughput Regeneration and Transformation Platform for Production of Genetically Modified Banana. Front. Plant Sci. 6:1025. doi: 10.3389/fpls.2015.01025

Tripathi, L., Ntui, V. O., and Tripathi, J. N. (2019). Application of genetic modification and genome editing for developing climate-smart banana. Food Energy Secur. 8:e00168. doi: 10.1002/fes3.168

Tzean, Y., Lee, M. C., Jan, H. H., Chiu, Y. S., Tu, T. C., Hou, B. H., et al. (2019). Cucumber mosaic virus-induced gene silencing in banana. Sci. Rep. 9:11553. doi: 10.1038/s41598-019-47962-3

Uga, Y., Okuno, K., and Yano, M. (2011). Dro1, a major QTL involved in deep rooting of rice under upland field conditions. J. Exp. Bot. 62, 2485-2494. doi: 10.1093/jxb/erq429

Velasquez Arredondo, H. I., Ruiz Colorado, A. A., and Junior, S. D. O. (2010). Ethanol production process from banana fruit and its lignocellulosic residues: Energy analysis. Energy 35, 3081-3087. doi: 10.1016/j.energy.2010.03. 052

Vuylsteke, D., and Langhe, E. (1985). Feasibility of in vitro propagation of bananas and plantains. Trop. Agric. 62, 323-328.

Wang, B., Smith, S. M., and Li, J. (2018). Genetic Regulation of Shoot Architecture. Annu. Rev. Plant Biol. 69, 437-468. doi: 10.1146/annurev-arplant-042817040422

Wang, H., Sun, S., Ge, W., Zhao, L., Hou, B., Wang, K., et al. (2020). Horizontal gene transfer of $F h b 7$ from fungus underlies Fusarium head blight resistance in wheat. Science 368:eaba5435. doi: 10.1126/science.aba5435

Wang, J., and Chen, H. (2020). A novel CRISPR/Cas9 system for efficiently generating Cas9-free multiplex mutants in Arabidopsis. aBIOTECH 1, 6-14. doi: 10.1007/s42994-019-00011-z
Wang, J., Zhou, L., Shi, H., Chern, M., Yu, H., Yi, H., et al. (2018). A single transcription factor promotes both yield and immunity in rice. Science 361, 1026-1028. doi: 10.1126/science.aat7675

Wang, T., Wei, J. J., Sabatini, D. M., and Lander, E. S. (2014). Genetic screens in human cells using the CRISPR-Cas9 system. Science 343, 80-84. doi: 10.1126/ science. 1246981

Wang, W., Feng, B., Zhou, J.-M., and Tang, D. (2020). Plant immune signaling: Advancing on two frontiers. J. Integr. Plant Biol. 62, 2-24. doi: 10.1111/jipb. 12898

Wang, Y., Zhao, J., Lu, W., and Deng, D. (2017). Gibberellin in plant height control: old player, new story. Plant Cell Rep. 36, 391-398. doi: 10.1007/s00299-0172104-5

Wang, Z., Miao, H., Liu, J., Xu, B., Yao, X., Xu, C., et al. (2019). Musa balbisiana genome reveals subgenome evolution and functional divergence. Nat. Plants 5 , 810-821. doi: 10.1038/s41477-019-0452-6

Wang, Z., Zhang, J., Jia, C., Liu, J., Li, Y., Yin, X., et al. (2012). De novo characterization of the banana root transcriptome and analysis of gene expression under Fusarium oxysporum f. sp. Cubense tropical race 4 infection. BMC Genom. 13:650. doi: 10.1186/1471-2164-13-650

Widinugraheni, S., Niño-Sánchez, J., van der Does, H. C., van Dam, P., GarcíaBastidas, F. A., Subandiyah, S., et al. (2018). A SIX1 homolog in Fusarium oxysporum f.sp. cubense tropical race 4 contributes to virulence towards Cavendish banana. PLoS One 13:e0205896. doi: 10.1371/journal.pone.0205896

Woo, J. W., Kim, J., Kwon, S. I., Corvalán, C., Cho, S. W., Kim, H., et al. (2015). DNA-free genome editing in plants with preassembled CRISPR-Cas9 ribonucleoproteins. Nat. Biotechnol. 33, 1162-1164. doi: 10.1038/nbt.3389

Xu, G., Yuan, M., Ai, C., Liu, L., Zhuang, E., Karapetyan, S., et al. (2017). uORFmediated translation allows engineered plant disease resistance without fitness costs. Nature 545, 491-494. doi: 10.1038/nature22372

Xu, Y., Hu, W., Liu, J., Song, S., Hou, X., Jia, C., et al. (2020). An aquaporin gene MaPIP2-7 is involved in tolerance to drought, cold and salt stresses in transgenic banana (Musa acuminata L.). Plant Physiol. Biochem. 147, 66-76. doi: 10.1016/j.plaphy.2019.12.011

Yip, M. K., Lee, S. W., Su, K. C., Lin, Y. H., Chen, T. Y., and Feng, T. Y. (2011). An easy and efficient protocol in the production of $p f l p$ transgenic banana against Fusarium wilt. Plant Biotechnol. Rep. 5, 245-254. doi: 10.1007/s11816-0110179-y

Yu, H., and Zhao, Y. (2019). Fluorescence Marker-Assisted Isolation of Cas9Free and CRISPR-Edited Arabidopsis Plants. Methods Mol. Biol. 1917, 147-154. doi: 10.1007/978-1-4939-8991-1_11

Zhang, L., Cenci, A., Rouard, M., Zhang, D., Wang, Y., Tang, W., et al. (2019a). Transcriptomic analysis of resistant and susceptible banana corms in response to infection by Fusarium oxysporum f. sp. cubense tropical race 4. Sci. Rep. 9:8199. doi: 10.1038/s41598-019-44637-x

Zhang, L., Yuan, L., Staehelin, C., Li, Y., Ruan, J., Liang, Z., et al. (2019b). The LYSIN MOTIF-CONTAINING RECEPTOR-LIKE KINASE 1 protein of banana is required for perception of pathogenic and symbiotic signals. New Phytol. 223, 1530-1546. doi: 10.1111/nph.15888

Zhao, J., Wang, T., Wang, M., Liu, Y., Yuan, L., Gao, Y., et al. (2014). DWARF3 Participates in an SCF Complex and Associates with DWARF14 to Suppress Rice Shoot Branching. Plant Cell Physiol. 55, 1096-1109. doi: 10.1093/pcp/ pcu045

Zhou, X., and Huang, X. (2018). Genome-wide Association Studies in Rice: How to Solve the Low Power Problems? Mol. Plant 12, 10-12. doi: 10.1016/j.molp. 2018.11.010

Zhu, G., Wang, S., Huang, Z., Zhang, S., Liao, Q., Zhang, C., et al. (2018). Rewiring of the Fruit Metabolome in Tomato Breeding. Cell 172, 249-261.e. doi: 10.1016/ j.cell.2017.12.019

Conflict of Interest: The authors declare that the research was conducted in the absence of any commercial or financial relationships that could be construed as a potential conflict of interest.

Copyright (c) 2021 Wang, Yu and Li. This is an open-access article distributed under the terms of the Creative Commons Attribution License (CC BY). The use, distribution or reproduction in other forums is permitted, provided the original author(s) and the copyright owner(s) are credited and that the original publication in this journal is cited, in accordance with accepted academic practice. No use, distribution or reproduction is permitted which does not comply with these terms. 